$\begin{array}{r}\text { Volume and Issues Obtainable at Center for Sustainability Research and Consultancy } \\ \text { Journal of Business and Social Review in Emerging Economies } \\ \text { ISSN: 2519-089X (E): 2519-0326 } \\ \text { Volume 6: No. 4, December } 2020 \\ \text { JSRC } \\ \text { Journal homepage: www.publishing.globalcsrc.org/jbsee } \\ \hline\end{array}$

\title{
Police Brutality and Reforms in Pakistan
}

\section{Najma Sadiq ${ }^{1}$, Ume Laila ${ }^{2}$, Tahir Mehmood ${ }^{3}$, Tooba Rehan Haqqi ${ }^{4}$}

${ }^{\mathbf{1}}$ Assistant Professor, Head of the Department, Department of Mass Communication, School of Social Sciences and Humanities (S3H), National University of Sciences and Technology (NUST), Islamabad, Pakistan, najmasadiq@gmail.com

${ }^{2}$ Assistant Professor, Government \& Public Policy, School of Social Sciences and Humanities (S3H), National University of Sciences and Technology (NUST), H-12 Sector, Islamabad, Pakistan, dr.umelaila@s3h.nust.edu.pk

${ }^{3}$ Assistant Professor, Department of Communication studies, BahaUddin Zakariya University, Multan, Pakistan, tahirmahmood@bzu.edu.pk

${ }^{4}$ Graduate Public Administration, Department of Government \& Public Policy, National University of Sciences and Technology (NUST), H-12 Sector, Islamabad, Pakistan, Tooba.bpa16s3h@s3h.nust.edu.pk

\begin{tabular}{l}
\hline ARTICLE DETAILS \\
\hline History \\
Revised format: November \\
2020 \\
Available Online: December \\
2020 \\
\hline
\end{tabular}

Keywords

Police, Police Brutality, Pakistan, Police Reforms

\section{JEL Classification}

M10, M1
ABSTRACT

Police Brutality has become one of the most important highlight around the globe. This study qualitatively investigates the form of police violence existent in Pakistan and also how this violence is related with the reforms enunciated. Through investigation it has been seen that the police of Pakistan are more into bribery and misuse of power than it is there to serve the nation and provide national security. This study shall highlight important issues prevalent and will also provide recommendations through which issues can be resolved.

(C) 2020 Center for Sustainability Research and Consultancy Pakistan under a Creative Commons Attribution-NonCommercial-ShareAlike 4.0

Corresponding author's email address: najmasadiq@gmail.com

Recommended citation: Sadiq, N., Laila., U., Mehmood, T. \& Haqqi, T. R. (2020). Police Brutality and Reforms in Pakistan. Journal of Business and Social Review in Emerging Economies, 6(4), 13531359

\section{Introduction}

Police department is an integral department in any state in order to maintain law and order in the country. Pakistan being a democratic state has established a separate police department in order to protect the citizens of the country. Specialized training schools have been established which train the police officers in a way that they can sustain any danger and face challenges with bravery; not only that highest standards of merit are maintained in recruiting along with numerous perks and benefits endowed to the police personnel at all levels. The personnel are also given on-the-job training to keep them up to date. The force is fully equipped with latest machinery and are fully technologized in order to curb any violence prevalent in the society. 
When the police department was discovered, it was believed that through this modern criminology shall advent and through this new horizon the old forms of policing shall be laid to rest (Alan, 2005-2006). It was believed that the department is of local nature meaning it shall by all means work for the commo statemen but never it had been thought that this essential department would one day rise and become a robust institute that shall only be working for the elites and power. Despite investing abundant resources in this department, the results are not satisfactory. The police in here has become a violent force rather than a discipline maintaining department. Violence in police is a contradictory term, yet this ferocity is growing at a reckless speed. Such a type of violence in easy words can be referred to as misuse or mal exercising of power. The situation prevailing in United states has opened eyes of Pakistani people who have now started to talk and investigate about the ongoing brutality in Pakistan. George Floyd's video has caused a rage all around the world and this is the first time ever when people in Pakistan have started to support this issue through social media and thus have participated at international forum. This incident has exposed the real face of police and has led people to rethink the need for constabularies. Tip top preparing schools have been built up for the cops. Despite the courses of action fit as fiddle up these officials as the gatekeepers of the general population, the country is at times rewarded to the updates on a hardhearted killing on account of these very men.

It might not be wrong to say that the police department needs well trained, and physically and mentally perfect officers. Apart from these qualities, morale must be the topmost priority while selecting the officers (Gockce, 1945) . A lot of time is required to inject high moral standards into a person. The then, it was deemed and believed that a moral person is a just person but now, the modernized world has thrown back this quality and which can easily be seen in the police department also. It was once a time when police constables had the best of attitude and behavior, but all of the essence is now lost and seems like can never be restored back.

\subsection{Research Focus}

This essay shall investigate following important factors behind this violence

1. Relevance between different brutality cases

2. Factors behind police violence in Pakistan

3. Fate of police reforms enunciated in 2002

The purpose of this research is to evaluate the factors that are hyping the police violence and the significance of topic lies in the fact that no such research has been yet carried out to draw out the relevance between the reforms enunciated and how well did these reforms contributed to reduce the prevailing brutalities.

\section{Literature Review}

Police incarceration has become a norm in United States. Many black Africans are laid to rest due to immense culture of racism amongst white people and it might not be wrong to say that the U.S. criminal system is almost always silent on such issues and have had never supported the black Africans against this brutality (Taylor, 2013). The question then arises has there any reforms been initiated in order to curb this brutality or not? The question does stands out and it can easily be stated that no such reforms have come to light. The US department of Justice should consider the fact of humanity and start working against this brutality and should work hard enough to pledge rights for the black Africans (Chaney \& Robertson, 2013).

Terrorizing poor has become quite easy and a normal thing especially for the police officers. The protest carried out by Tamil-Nadu fishermen against the installation of nuclear power plant at the coastal lines was subjected to serious torture and anguish that by any means they had to back off from the protest (Kumar, 1985) . But can all this brutality and homicide against poor and mostly the religion of Islam justifiable? Can the events of 1962 in Los Angeles be justifies when 7 of the Muslims were laid to rest by the police when they had not even committed the slights of the slight crime. But its clearly evidential 
that the political authorities were quiet powerful in overcoming and shadowing these events and till date no such effort has ever been made to give due rights to those innocent Muslims (Knight, 1994).

In some cases like China, police department is the most loyal where they work day and night to administer and resolve the cases, but here in China the work load on police officers is so vast that this has become the matter of frustration and has become difficult for them to accomplish set goals (E. SCOGGINS \& O'BRIEN, 2016) . Unlike this in Japan it is believed that the police department might be much worst than it even appears to be. Three most galvanizing corruptions have been observed in this department which requires a lot of attention (Johnson, 2003). Little to no research has been carried out in Pakistan to evaluate and find the reasons behind the prevailing conditions in the police department. In a research carried out by Mukarram Ali Khan, he has pointed out the police brutality in Pakistan explaining the different forms in which it exists and has justified by giving reasons and pointing out incidents which has led to such circumstances. On taking interviews, the stakeholders jagged out different states and forces which have started to worsen the police department conditions (Mukaram, 2014). In another research chapter, by Zubair Nawaz Chattha and Sanja KutnjakIvković, they have highlighted police misconduct and have justified the prevailing condition by mentioning certain socioeconomic and political conditions which are heeding the viciousness (Zubair \& Sanja).

In an article named "Police and Policing in Pakistan" by Fasihuddin, the researcher has pointed out the effects of Police Order 2002 and to what extent it has created drastic changes in the police sector. The author has also explained the structural problems still prevalent in the organization. Comprehensively, the author believes that apart from 1886 police order no reforms have created a positive impact or has improved the police sector. Certain suggestions are also presented which can easily be incorporated in order to improve and enhance the functional capacity of this important sector (Fasihuddin, 2019).

Abbas Ahsan in his article "Police Reforms: Public Perception and Introspection" clearly mentions that there is a dire need of reforms in the police sector of Pakistan. He believes that integrity and accountability are the two missing factors in this sector and hence require a lot of attention. The author believes that the reforms shall not be fruitful unless and until the perception of public related to the police is known. He confidently points out that the negative perception of people regarding the police sector truly reflects the reality of this sector and unless and until the policy makers truly understand the insight of public no such reforms can be enunciated (Ahsan, 2019, pp. 155-162).

Aftab and Baloch have investigated the nature of the foundations on which the Sindh Policing system has been laid. In their article "Policing Colonization The Evolution and Role of Sind Police and the Views of Sir Charles Napier on the Administration of Criminal Justice in Sind" evaluates the working capacity of the Sindh Police prior to the formation of Pakistan. They believe that the British policing system did had some drawbacks including the operational deficiencies as well as a lot of influence of the jagir system has been seen. The authors believe that the present Sind Police system still has these deficiencies and thus a lot of improvement is required (Aftab \& Dost, 2019).

Paul Petzschmann in his brief article pointed out the major institutional setbacks after carrying out a survey. The Author in his article "Police Reform in Pakistan A Victim of Foreign Security Aid?" claims that the police sector started to deteriorate after the reforms enunciated by former President Musharraf. He believes that the only thing Pakistani police is good at is to combat Talibanization or to fight war against the terror. he also puts a question before the government that whether the police reforms were implemented to modify the sector or to attract the foreign aid. He articulates that the true essence of police department has been lost and that essential reforms are required in terms of training so that the officers get to know that the main thing is to provide security to general public and not to protect the politicians and borders (Paul, 2010). 


\section{Research Methodology}

This research follows qualitative approach and investigates into different scenarios reported in news and other articles talking in detail about the police brutality. Also, posted documents of Police Ordinance have been obtained from the website of Law Enforcement Agencies. The documents have been reflected and studied thoroughly before framing a contextual relationship between how the fate of PO 2002 has been subjected to threat.

\section{Analysis}

The Following part now discuses in detail the three objectives of this research. The analysis is purely descriptive in nature, followed by relevant examples and cases where necessary.

\subsection{Police Reforms and its Fate}

After independence Pakistan had established a criminal justice system under which police department was destined to provide security to the nation. With the passage of time this division started to come under different influences, majorly the political influence. With the interference of ruling political authority corruption and red tapes began to increase and thus police department's efficiency began to diminish. Till date this department is sheerly involved in crooked activities. Upon considering the diminishing health of the department the federal government decided to introduce certain reforms in this department. The police reforms 2002, enunciated on 14th august 2002, were the hallmark as officials along with nation though that this decision will finally allow them to put trust on the constabularies. The police order at that time imposed legal obligations on the police authorities to execute and exercise their powers justly and that they were destined to exhibit highest standards of morality, professionalism, nationalism and of course justice. Perceiving that these officials shall remain friendly certain autonomies and immunities were also granted to shelter police officials. But soon after provinces were given autonomy to make their own decision except Punjab the remain three provinces drafted and implemented their own Police orders. This created a rift in the police officials all over the country who were not bound by one contract rather subjected to different regulations.

The legitimacy of the Police Order 2002 (CDPI, 2013) became questionable soon after the 18th amendment. The authorities tried their level best to restore uniformity in police regulations all over the country but failed to do so. However, it was then decided that Model Police Law 2018 should be applicable in provinces was flexible enough to accommodate the requirements of the provinces and the Police Order 2002 be applicable only on Islamabad. But things stand out very clear; there was an absolute lack of political will due to which these reforms could not be enforced. Without having a uniform codified system applied all over the country efficiency, effectiveness and justice cannot be achieved in the criminal justice system. Recently, Islamabad High Court called a hearing in which the matter of non-implementation of PO-2002 was discussed. Chief Justice Minhallah demanded reasons along with evidences regarding why this reform had not been enforced despite promulgated 18 years ago, but to utmost surprise they authorities very cleverly shifted the blame onto the civil government claiming that such reforms do not cohere with the thinking and requirements of general public. Having said that they also demanded to abolish this reform constitutionally and let provinces decide the fate of police department on their own. But in my opinion, this is not a way to deal with issues. The constitutionally promulgated reforms should not be called off this easily only because the political authorities cannot have their personal motives fulfilled. It should be noted that until and unless politics is separated from police department nothing can be changed.

Moreover, the 2002 and other so-called modernized police reforms failed due to antagonism and hostility of Civil Bureaucracy. These reforms restricted the control of district magistrate over the police and hence faced unwarranted backlashes. The bureaucracy then made serious efforts not to implement such reforms and exerted extreme pressure on the political elite and other concerned agencies to amend the new legislation. Hence here the point is raised that if such kind of corrupt officials keep on enjoying the positions falsely and disregard the true essence of bureaucracy then the departments under 
establishment can never be reformed and can never be corruption free.

\subsection{Relevance between Different Brutality Cases}

Police brutality has now become a global phenomenon. Every day almost new cases related to police harshness emerge. From the video that went viral of George Floyd numerous questions have cam forward in the domestic media calling out and challenging the concerned authorities to look for the rampant police brutality here in Pakistan. It is evidential form the incidents that police authorities have had disregarded the norms and values of justice system and have shown inhumane attitude while subjecting the common man to the brutal behavior letting it be verbal abuse or torturing in-custody criminals to death. Not only that they have also defied and disregarded the constitutional and fundamental human rights but there exists no law which would subject them to inquiries.

Such frequencies have shown the real face of the police department and have indicated that the police have started to misuse the brand or name which they should be using to serve the people. an inflexion point and many Americans can completely relate. The ongoing protests in America do have a 100\% relevance to what is happening here in Pakistan but the difference lies in a way that there people took the case onto the streets while here in Pakistan nobody has that freedom to go against the police brutality and speak openly on media. Staring from the incident that occurred in 2018, when Naqeeb ullah mehsud was killed by super intended in Karachi claiming that he was involved in certain terrorist activities. A wave of anger had swept around the country at that time, but nobody was able to acquire justice for the young lad because police had started to threaten deceased's family. Many NGO's and other human rights organizations called for investigations but of no use; soon after the case was closed, and no interrogations were carried out on the part of SP police Karachi. Another incident which occurred in Lahore where police constables tortured a mentally challenged person to death and again despite many efforts those constables could not be held accountable. Recently, in Karachi a frontline doctor was shot twice by a policeman and upon confrontation with the higher authorities they claimed that, the policeman had some psychic problem so he cannot be dragged into the court of law of inquiries. So here comes the question if he had been a mentally ill person what he was doing in the police department. Again, law remained silence and could not stand up for the frontline doctor who risked his life in this pandemic.

Certain relevance can be drawn in these cases. In all the three scenarios its clear that the police had misused the power and immunity endowed upon them and simultaneously the weak justice system was unable to held accountable these people. In almost $90 \%$ of the cases it's a weak or person belonging to marginalized groups who are subjected to the police violence. In the remaining $10 \%$ the police mal-used their powers. Here in Pakistan police considers themselves above law and that they have power to do ANYTHING without being accountable before the law. These situations arise because of the weak judicial system which just plays a puppet show and remains silent before the political influences and other powerful establishments.

\subsection{Factors behind Police Violent in Pakistan}

The police brutality prevalent in USA is because of the racial differences. Almost $99 \%$ of people subjected to this violence are the black Americans. But here in Pakistan there are numerous other factors which gave rise to the police ferocity. Upon investigation the results turned out to not so surprising. The main factors which have heeded up the situation include:

1. Lack of proper training, knowledge and resources

2. Lack of proper funding, which leads to low salaries and thus enhancing the frustrations.

3. Meager working; which means that the people working in police department are not been provided with certain way outs, only they must do is to listen to orders of their bosses.

4. Absence of coordination between the law enforcement agencies which makes the police department all in all. Lack of synchronization also leads to no controlling agency/power over the department. 


\section{Recommendations}

As things can never be left out alone similarly this vicious department of the society cannot be left out to erode on its own. Frequently, police are part of the problem, as opposed to be its solution. Similarly, in most cases the police officers turn out to be way too corrupt defying and disregarding all sorts of requirements of justice. In other circumstances the nation does not trust the constabularies; but every problem has a solution. There exist some opportunities through which things or moreover department can be revamped. Following are some recommendations through which police department can be set on the road to progress.

FIRSTLY, the government should restrict the powers of police by enforcing the already present Article 14 of constitution which decrees that "no action detrimental to the life, liberty, body, reputation or property of any person shall be taken except in accordance with law" and that no person "shall be deprived of life or liberty save in accordance with law" (GOP, 1973). Through administering this provision police department will be considered under law and not above the eyes of law. "Criminal Procedure Code (1898), the Maintenance of Public Order Ordinance (1960), and the recently enacted Protection of Pakistan Act (2014), all contribute to a legal framework that protects the police from accountability" moreover, QUALIFIED IMMUNITY, which gives them an escape goat to misuse designated powers and no one will be questioning them. In my opinion this should be eliminated from the system as it makes the police different from all of us and it must be made sure that any person who does bad should reap the fruit of his doings.

SECONDLY, the police department here in Pakistan should be demilitarized. By demilitarize it means that the department must be restricted, and it should be made sure that none of the officials are using federal funds to buy equipment that are out of the scope for the department. For instance, police raid houses with heavily equipped guns, they should be restricted to baton; charge and pistols not more than that. Also, enough instruction should be given to them so that they know when and how to use such things.

THIRDLY, any police officer who comes across such heinous crime of brutally killing and torturing a criminal or as stated in the above examples these police officers must be prosecuted, dragged in the court of law, charge them as hard as the prosecutor can and then finally should be given punishment in accordance to what the penal code says regarding the murder/torture to death. Unless and until such actions are taken in the past cases, no police officer shall abide by misusing the powers. It's now in the hands of the criminal justice system either it decides to feed the officials or serve the nation without any discrimination.

FOURTHLY, although the following recommendation should be employed on all departments but particularly in the police division. This sector should be made free from the political influence and interference. For so long politicians have started to fuel and bribe police officials and have for so long kept them as their pets. Such misdealing inhibits the common man to completely trust the police and acquire any sort of help.

FIFTHLY, the criminal justice system should be revamped at priority basis and should be made more responsive to the victims. In order to revamp this system a quantitative approach of statistical analysis should be adopted which will, through surveys, allow the judiciary to investigate the reasons behind the violence and the trend. Moreover, the justice system should be strong enough to held accountable officials and must not fear someone because of the position the hold in the society. If a case of brutality comes forward the justice department should compel the police authorities to provide data of the official attempting such brutality and then the trial should be carried out. If in case the justice system fails to do so a condition should be levied that the justice department shall not be receiving any sort of federal funding to run the department. 


\section{Conclusion}

This essay does not aim to highlight and spread negativity about the police department; but the reason behind writing this essay is to make sure that the concerned authorities find a way forward and get a chance to restore this subdivision. "The strength and legitimacy of the police forces depends upon how morally they perform the duty; one such is the example of the police force of Georgia. People living there do not abide by the rules and regulations just because of the fear that they might lose their livesinstead, they listen to a traffic warden, or a constable, or a senior official, out of respect for the law, and respect for the symbol of the State that their uniform represents. Unfortunately, in Pakistan, this ethical dilemma of the police department has worn out. For now, the people of Pakistan are at war: with the militant, and with a police force that frequently acts in the same manner that militants do. This model is as unjustifiable, and it is time for meticulous members within the police force to retrieve the promise of their profession and restate themselves as sympathetic and empathetic guardians of nation". Moreover, if we really want to make the police department really effective we need to incorporate three things; measuring the performance of the department against a set criterion, maintain completely audited records which may be used at any time in order to measure the performance, and lastly methodologies which must be adopted by each and every individual of the department to make things possible (D. Parrat, 1938).

\section{References}

Aftab, N., \& Dost, A. B. (2019). Policing Colonisation The Evolution and Role of Sind Police and the Views of Sir Charles Napier on the Administration of Criminal Justice in Sind. Pakistan Journa of Criminology .

Ahsan, A. (2019). Police Reforms: Public Perception and Introspection . Pakistan Journal of Criminology .

Alan, D. (2005-2006). Not Your Father's Police Department: Making Sense of the New Demographics of Law Enforcement. Journal of Criminal Law and Criminology .

CDPI, P. (2013, March). Retrieved from http://www.cpdi-pakistan.org/wpcontent/uploads/2013/04/Police_Order_2002_e.pdf

Chaney, C., \& Robertson, R. V. (2013). Racism and Police Brutality in America. Journal of African American Studies, 480-505.

D. Parrat, S. (1938). How Effective Is a Police Department? The Annals of the American Academy of Political and Social Science, 153-164.

E. SCOGGINS, S., \& O'BRIEN, K. J. (2016). China's Unhappy Police. Asian Survey, 225-242.

Fasihuddin. (2019). Police and Policing in Pakistan . Pakistan Journal of Criminology , http://www.pjcriminology.com/publications/police-and-policing-in-pakistan/.

Gockce, B. W. (1945). Morale in a Police Department. Journal of Criminal Law and Criminology, 215219.

GOP. (1973). Constitution of Pakistan .

Johnson, D. T. (2003). Above the Law? Police Integrity in Japan. Social Science Japan Journal, 19-37.

Knight, F. (1994). Justifiable Homicide, Police Brutality, or Governmental Repression? The 1962 Los Angeles Police Shooting of Seven Members of the Nation of Islam. The Journal of Negro History, 182-196.

Kumar, K. G. (1985). Police Brutality Besieges Ecology: National Fishermen's March. Economic and olitical Weekly, 1155.

Mukaram, K. (2014). Police Violence in Pakistan: Forms and Justifications. Research Gate.

Paul, P. (2010). Police Reform in Pakistan A victin of Foreugn Security Aid? . Pakistan Journal of Criminology .

Taylor, C. (2013). INTRODUCTION: AFRICAN AMERICANS, POLICE BRUTALITY, AND THE U.S. CRIMINAL JUSTICE SYSTEM. The Journal of African American History, 200-204.

Zubair, N. C., \& Sanja, K. I. (n.d.). Police Misconduct: The Pakistani Paradigm. In The Contours of Police Integrity (p. chapter 10). Sage books. 